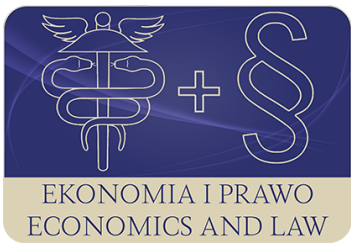

EKONOMIA I PRAWO. ECONOMICS AND LAW

Volume 20, Issue 3, September 2021

p-ISSN 1898-2255, e-ISSN 2392-1625

www.economicsandlaw.pl

ORIGINAL ARTICLE

received 04.03.2021; revised 10.09.2021; accepted 30.09.2021

Citation: Brózda-Wilamek, D. (2021). The impact of the Federal Reserve System's interest rate channel on the components of aggregate demand. Ekonomia i Prawo. Economics and Law, 20(3), 479-496. https://doi.org/10.12775/EiP.2021.029.

\title{
The impact of the Federal Reserve System's interest rate channel on the components of aggregate demand
}

\author{
DOMINIKA BRÓZDA-WILAMEK \\ University of Lodz, Faculty of Economics and Sociology, Department of International Business \\ and Trade, ul. 3/5 POW, 90-255 Lodz, Poland \\ $\square$ dominika.brozda@uni.lodz.pl \\ (D) orcid.org/0000-0002-0513-2286
}

\begin{abstract}
Motivation: Monetary policy decisions, through the process of transmission mechanism, affect the term structure of nominal interest rates as well as other asset prices, and thus influences aggregate demand (e.g. consumer spending and business investments)

and price levels through these effects. The aspect of monetary transmission to various components of aggregate demand has been relatively little studied in the literature of the subject.

Aim: The main aim of the study is to empirically investigate the effect of the Fed's monetary policy on major components of aggregate demand over the past 35 years. To this aim, the scale and timing of the interest rate pass-through to economic activity have been examined.

Results: The empirical findings showed that that between 1984 and 2019, the sensitivity of consumption and investment expenditures to interest rate impulses were different. Firstly, fixed investment spending accounted for a significant part that was responsible for the response of real GDP following an interest rate shock. Secondly, in the case of personal consumption expenditures, expenses for durable goods were more sensitive to changes in the Fed's interest rate than spending on services and nondurable goods. In this way, the study expands the existing literature by reporting the effects of the Fed's monetary policy on major components of aggregate demand over the past 35 years
\end{abstract}


Keywords: monetary policy; interest rate; monetary transmission mechanism; Federal Reserve System; aggregate demand

JEL: E43; E52; E58

\section{Introduction}

The monetary policy of the Federal Reserve System (Fed), like the monetary policy of any other central bank, affects the term structure of nominal interest rates as well as other asset prices, and thus influences aggregate demand and price levels through these effects (Akhtar, 1997, p. 10). This complex process is known as the monetary transmission mechanism (MTM), which has changed over time but remains a 'black box' (Bernanke \& Gertler, 1995, p. 27). Mishkin (1996, pp. 1-15) distinguishes four basic channels of the monetary policy transmission mechanism, i.e.: the interest rate channel, the exchange rate channel, the credit channel, and the asset price channel. The transmission mechanism is characterized by long, variable, and uncertain time lags. Thus, it is difficult to predict the precise effect of monetary policy actions on economic activity.

It is worth emphasizing that after monetary policy tightening, for instance, a given decline in the aggregate demand coming from different sectors of the economy has various macroeconomic implications. The rise in the central bank's interest rate might push households to postpone some of their planned spendings and save more. The same higher interest rates might also cause investments to be more costly and thus temporarily slow down investment processes in the economy. While both will reduce aggregate demand, the resulting slowdown in investment might have longer-term growth implications in contrast to a slowdown originating from a decline in consumer demand (Khundrakpam, 2012, p. 2). Therefore, to better understand the MTM, it is important to identify in which areas of the economy the monetary policy influence is felt most.

The article aims to assess the effect of the Fed's monetary policy on major components of aggregate demand over the past 35 years. In particular, the scale and timing of the interest rate pass-through to economic activity have been examined. In order to realize the objective of this paper, the formulated research hypothesis stated that between 1984 and 2019 Fed's unexpected monetary shocks (change in interest rate) affect aggregate demand mainly through its impact on fixed investment. The verification of this research hypothesis was conducted by using an econometric method - the vector autoregression (VAR) model. The empirical analysis was carried out based on U.S. economic statistics for the years 1984-2019, which were taken from the FRED and BEA Databases.

The rest of the article is structured as follows. The next section explains the essence of the interest rate channel. Section 3 briefly reviews the literature on the subject. Section 4 describes methodological issues, especially the research sample and assumptions of the model. Section 5 offers empirical results. Finally, section 6 presents summarizing and concluding remarks of the paper. 


\section{Literature review}

The main channel of the MTM is the interest rate channel. Mishkin (1996, p. 2) indicates that the transmission of monetary policy through interest rate mechanisms is associated with both the Keynesian IS-LM model and the aggregate demand-aggregate supply (AD-AS) model. The traditional interest rate channel can be characterized by a schematic diagram (1):

$$
M \uparrow \rightarrow i \downarrow \rightarrow l i \downarrow \rightarrow I \uparrow C \uparrow \rightarrow Y \uparrow,
$$

where:

$M \uparrow-$ expansionary monetary policy;

$i$ - nominal interest rate;

li- long-term interest rate;

$I$ - investment expenditures;

$\mathrm{C}$ - consumption expenditures;

$Y$ - aggregate demand.

Analyzing the above chain of relationships, it can be seen that an expansionary monetary policy involves cutting short-term interest rates, followed by commercial banks offering lower interest rates for loans and deposits. This then causes a decrease in long-term interest rates, which affects consumption, saving, and investment decisions. The reduced level of interest rates increases the propensity to invest in the economy. Movements in the interest rate affect fixed investment through the user cost of capital. Lower interest rates reduce the required return from investment projects and raise the rate of business investment.

Changes in official interest rates also influence households' income and consumption decisions. Lower interest rates decrease the propensity to save make present consumption less expensive relative to future consumption. Providing that households are net debtors, a fall in interest rates raises the value of lifetime income, further growing consumer demand (Bean et al., 2002, p. 13). As a result, the extension in consumption and investment expenditure increases inflationary pressure, thereby leading to boost economic activity.

Notably, it is worth noting that even if the short-term interest rate is blocked at zero lower bound on nominal interest rates (ZLB), the central bank can still have an impact on aggregate output and prices by increasing liquidity through massive amounts of asset purchases (Mishkin, 1996, p. 3). In this case, the diagram (l) can be written differently as follows:

$$
M \uparrow \rightarrow P^{e} \uparrow \rightarrow \pi^{e} \uparrow \rightarrow i_{r} \downarrow \rightarrow I \uparrow C \uparrow \rightarrow Y \uparrow,
$$

where:

$P^{e}$ - expected price level;

$\pi^{e}$ - expected inflation;

$i_{r}$ - real interest rates. 
Under the very low nominal interest rates, large-scale asset purchases (LSAP), also known as quantitative easing (QE) programs, together with forward guidance influence long-term interest rates through reducing the term premium or stimulating inflation expectation (Brózda, 2016, pp. 757-766). This results in the reduction of real interest rates, which then have a favorable effect on consumer spending and investment expenditure in the economy (Khemraj \& Yu, 2016, p. 2625).

Empirical studies have been conducted on the transmission mechanism of the Federal Reserve System's monetary policy in the United States since the early 1990s. They have appeared relatively often in the literature, from the works of Bernanke \& Blinder (1992, pp. 901-921), through the work of Brunner (1994, pp. 1-46), to the article by Walsh (2014, pp. 1-60), Endut et al. (2018, pp. 959-987) and Brózda-Wilamek (2020, pp. 163-182). Hoverer, the aspect of monetary transmission to various components of aggregate demand has been relatively little studied in the literature of the subject.

Particularly interesting are the results of a study that was carried out by Christiano et al. (2005, pp. 1-45). They use the model for the U.S. economy that not only reproduces the dynamic response of inflation and output but also accounts for, among others, the delay response in consumption and investment expenditures. The results suggest that after an expansionary monetary policy shock, output, consumption, and investment respond in a hump-shaped fashion, peaking after about one and a half years and returning to pre-shock levels after about three years.

The relative importance of individual economic sectors in transmission monetary policy impulses might differ significantly across countries. For instance, Angeloni et al. (2003, pp. 1265-1306) compared the reaction of consumption and investment expenditures to monetary policy shock in the euro area and the U.S. Their study indicated that following unexpected monetary tightening, various GDP components contribute to the economic slowdown to different extents. While in the U.S., the drop in private consumption dominated, the effect on investments seems to be more significant in the euro area.

However, Angeloni et al. (2003, pp. 1265-1306) and Christiano et al. (2005, pp. 1-45) investigated the response of aggregate consumption and investment to a monetary policy shock but did not specifically examine the response of consumer durables goods or residential investment. At this point, particularly noteworthy are the studies of Erceg \& Levin (2006, pp. 1341-1359), Monacelli (2009, pp. 242-254), and Walsh (2014, pp. 5-10). The economists documented that the durable consumption sector is much more interest-sensitive than the rest of the economy since most consumers use debt to finance the purchase of long-lasting goods.

Erceg \& Levin (2006, pp. 1341-1359) perform a VAR analysis of quarterly U.S. national accounts data, disaggregated into spending and prices for consumer durables spending (which includes residential investment). The results suggest that a monetary policy innovation causes a decline in consumer durables 
spending that is over three times larger than for the other expenditures. Spending on consumer durables exhibits a peak decline of about $0.7 \%$ in the third quarter following the shock, while the maximum response of spending on other GDP components is only $0.2 \%$.

The VAR model estimate by Walsh (2014, pp. 5-10) indicates that between 1970 and 2007, a rise in nominal interest rate led to a significant decline in real GDP, consumption, and real investment. It is worth emphasizing that in Walsh's (2014, pp. 5-10) study, consumption and investment were disaggregated into durables, nondurables, and services expenditures for consumption, and residential and nonresidential for investment. For investment, in particular, a positive interest rate impulse has had a statistically significant negative effect on total investment arising from its effect on residential investment.

The latest research on the Fed's monetary transmission mechanism has focused on the effects of unconventional monetary policy measures that were taken by the Fed during the last global financial crisis. Particular attention was paid to the problem of the ZLB. In general, it may be concluded that unconventional monetary policy instruments have had a positive impact on the real economy by lowering the level of long-term interest rates, which is confirmed by the results of studies by Christiano et al. (2015, p. 110-167), Chung et al. (2011, pp. 1-5) or among others. Moreover, Sims \& Wu (2020, p. 356) argued that forward guidance and QE may be effective substitutes for conventional rate decrease at the ZLB.

Notably, only a few studies focus on the impact of the Fed's unconventional monetary policy actions on the components of aggregate demand. In most of them, these effects were ignored or considered in a very limited range. For example, Khemraj \& Yu (2016, pp. 2625-2635) examined the effect of the Fed's LSAP only on private investment. They pointed out tentative evidence that QE stimulated the level of aggregate investment through the interest rate channel by narrowing corporate bond spread. In turn, van Zandweghe \& Braxton (2013, p. 24 ) found the weakened sensitivity of durable goods purchases to falling interest rates during the current economic recovery. They claimed that this decline might reduce the effectiveness of the Fed's monetary policy after the recent global financial crisis.

Building on the existing research gaps as discussed above, this study attempts to answer the research questions: Which component of aggregate demand seems to play a key role in the U.S. monetary transmission mechanism?

\section{Methods}

To assess the effect of the Fed's interest rate channel on major components of aggregate demand between 1984 and 2019, a vector autoregression model (VAR) was employed, which was disseminated in the economic literature by Litterman \& Weiss (1985, pp. 129-156) and Sims (1980, pp. 1-48). This research tool is used to measure the response of aggregate output and prices to a mone- 
tary policy shock on the economy. Notable examples of such empirical analysis of the monetary transmission mechanism can be found in Boivin \& Giannoni (2002, pp. 97-111), Brózda-Wilamek (2020, pp. 163-182), Christiano et al. (1999, pp. 65-148) or among others.

Although VAR is the most common method in analysing the response to monetary policy shocks, there are some limitations to this approach. First of all, the VAR model focuses on shocks, so this method is useless to analyse response to systematic movements of Fed (as these resulting from Taylor rules), which are the most common elements of monetary policy. Secondly, critics of the VAR model find that it impossible that the Fed behaves unpredictably and maintain that the "shocks" really represent either model specification errors or changes in the overall policy regime (see Cochrane, 1998, pp. 277-300; Rudebusch, 1998, pp. 907-931).

Despite these criticisms, analysis of the results of the VAR model estimation might make it possible to determine the manner, strength, and degree of impact of the Fed's interest rate policy on the U.S. economy. In particular, in this paper, this approach was used to investigate the extent to which a monetary policy innovation has differential effects on major sectors of the economy.

In this study, a simplified specification of the VAR model was employed, which contained a set of four variables, i.e., real GDP (components of aggregate demand respectively), inflation, the Fed's interest rate, and the long-term interest rate. In order to compare the relationship between changes in the Fed's interest rate and American economic activity over the past 35 years, two VAR models for different time intervals were estimated, i.e.:

- the model I, in which the sample covered the period from the first quarter of 1984 up to the 3rd quarter of 2007;

- model II, in which the period from the fourth quarter of 2007 until the 3rd quarter of 2019 was considered.

Before estimating the VAR model using the Ordinary Least Squares (OLS) method, the time series were tested for the presence of the unit roots, since the desirable feature of the VAR system is its stationary nature. Nonstationary levels of the variables representing the U.S. economy have forced the transformation of the functional form of the model by using the first differences in natural logarithms for individual variables. Since the study included quarterly data, the first differences of the variables (annualised) were calculated according to the following formula:

$$
\Delta x_{t}=\left[\ln \left(x_{t}\right)-\ln \left(x_{t-1}\right)\right] \times 4,
$$

where:

$\Delta-$ the first differences operator;

$x_{t}$ - the value of the variable $x$ in period $t$

$x_{t-1}$ - the value of the variable $x$ in period $t-1$.

Modification of the variable representing the level of interest rates (i.e. calculation the first differences of the interest rates) would result in the loss of crit- 
ical information from the point of view of this study. For this reason, ultimately, VAR models that incorporate interest rate levels were estimated. This practice is widely used in the current empirical analyzes on the effects of monetary policy in the U.S. economy, as might be seen in a study conducted by, among others, Endut et al. (2018, p. 968) and Höppner et al. (2008, p. 2356).

In the first VAR model, the effective federal funds rate was taken into account as the variable determining the level of the official Fed interest rate. This interest rate is commonly used in research on the monetary transmission mechanism of the Federal Reserve System (see Bernanke \& Blinder, 1992, pp. 901921). In turn, in the second VAR model, which takes into account the period of the ZLB, the monetary policy impulse is approximated by the shadow federal funds rate, estimated by Wu \& Xia (2016, pp. 253-291). Sims \& Wu (2020, p. 350 ) and van Zandweghe (2015, pp. 46-47) emphasize that the shadow federal funds rate is a very useful way to summarize the effects of unconventional monetary policy actions. The shadow federal funds rate provides a measure based on longer-term bond prices. Especially, it makes use of models of the term structure to deduce a hypothetical value of short-term interest rates from the behavior of long-term rates as if there were no ZLB. The main advantage of such a VAR model specification is that the shadow federal funds rate is not limited by the zero lower bound and adopts negative values from mid-2009 to the end of 2015 (see Chart 1).

In order to assess the stationarity of variables the Augmented Dickey-Fuller test $(\mathrm{ADF})^{1}$ results were presented in Table 1 . It might be noticed that the first differences of the variables representing the real sphere of the U.S economy and price index are stationary (for all time intervals), which means that including them in the final VAR model increases the likelihood of obtaining reliable results. However, in a few cases, the boundary significance levels of ADF test statistics is greater than the adopted significance level of 0.05 , which may indicate the nonstationarity of these time series. In particular, this situation concerns the growth rate of real services expenditures.

Due to the low power of the unit root test (Zivot \& Wang, 2006, p. 132), in the study, the KPSS test (Kwiatkowski et al., 1992, pp. 159-178) was also used. In contrast to the ADF test, the null hypothesis of the KPSS test assumes the stationarity of the process. The results summarized in Table 2 . indicate that the majority of the variables included in the study are stationary at a significance level of 0.10 .

The lag value of the VAR models was determined as a result of the information criteria, which include the information criterion of Akaike (AIC), Schwarz (BIC), and Hannan-Quinn (HQ) (Zivot \& Wang, 2006, p. 390). Based on the data presented in Table 3 , the study adopted two lags (i.e., two quarters) between the independent variables and the dependent variable.

${ }^{1}$ In the ADF test, the null hypothesis assumes a unit root is present in time series against the alternative hypothesis (the process is stationary). 
The single VAR model used in this study for four endogenous variables consists of four equations with an identical structure. In each equation, all variables are included in the system, as explanatory variables, but they are delayed by two quarters. The general form of the model can be written as follows Stock \& Watson (2001, p. 101):

$$
x_{t}=A_{0} D_{t}+A_{1} x_{t-1}+A_{2} x_{t-2}+\varepsilon_{t},
$$

where:

$D_{\mathrm{t}}$ - vector of deterministic variables;

$A_{0}$ - parameter matrix $(4 \times 1)$ represents deterministic variables;

$A_{i}$ - coefficient matrix $(4 \times 4)$ represents delays of the endogenous variables $(\mathrm{i}=1,2, \ldots)$;

$\varepsilon_{t}-4$-dimensional vector of random components $(4 \times 1)$;

$x_{t}$ - vector of endogenous variables, which respectively takes the form for the following:

$$
x_{t}=\left[\Delta G D P_{t} \Delta p_{t} i_{t} z_{t}\right]^{\prime}
$$

$x_{t}=\left[\Delta P C E_{t} \Delta p_{t} i_{t} z_{t}\right]^{\prime}$

$x_{t}=\left[\Delta D G_{t} \Delta p_{t} i_{t} z_{t}\right]^{\prime}$

$x_{t}=\left[\Delta N D_{t} \Delta p_{t} i_{t} z_{t}\right]^{\prime}$

$x_{t}=\left[\Delta S_{t} \Delta p_{t} i_{t} z_{t}\right]^{\prime}$

$x_{t}=\left[\Delta F I_{t} \Delta p_{t} i_{t} z_{t}\right]^{\prime}$

$x_{t}=\left[\Delta N R_{t} \Delta p_{t} i_{t} z_{t}\right]^{\prime} ;$

$x_{t}=\left[\Delta R_{t} \Delta p_{t} i_{t} z_{t}\right]^{\prime} ;$

$G D P_{t}$ - the natural logarithm of real GDP, seasonally adjusted;

$p_{t}$ - the natural logarithm of the CPI, seasonally adjusted;

$i_{t}$ - the average level of effective federal funds rate, the (in the I model); the average level of the $\mathrm{Wu}$-Xia shadow federal funds rate (in the II model);

$z_{t}$ - the 10-year treasury constant maturity rate, the average level;

$P C E_{t}$ - the natural logarithm of real personal consumption expenditures, seasonally adjusted;

$D G_{t}$ - the natural logarithm of real durable goods expenditures, seasonally adjusted; 
$\mathrm{ND}_{t}$ - the natural logarithm of real nondurable goods expenditures, seasonally adjusted;

$S_{t}$ - the natural logarithm of real services expenditures, seasonally adjusted;

$\mathrm{FI}_{\mathrm{t}}$ - the natural logarithm of real fixed investment, seasonally adjusted;

$N R_{t}$ - the natural logarithm of real nonresidential investment, seasonally adjusted;

$R_{t}$ - the natural logarithm of real residential investment, seasonally adjusted.

The components of real GDP indicated above are significant from the point of view of the interest rate channel functioning. Moreover, it should be emphasized that due to the specific position of the U.S. dollar in inter-national finance, we have omitted the effect of the effective federal funds rate on net export, which largely depends on changes in the exchange rate. Government spending was also not included in this study, due to it largely depending on political decisions and fiscal policy.

The VAR model is useful for research when the development of endogenous processes in relation to random components is convergent and produces stationary processes. The basic assumption of the practical application of the VAR model is the condition which indicates that all elements of the characteristic polynomial should be less than one module.

The Inverse Roots of the AR Characteristic Polynomial for the VAR I and II models indicate that all roots of characteristics polynomial lie inside the unit circle, which is an indication that the VAR models satisfy the stability condition and have good properties. After using the VAR model, impulse response functions (IRFs) ${ }^{2}$ and forecast error variance decompositions (FEVD) ${ }^{3}$ of variables can be produced. Both computations are useful in assessing how shocks to economic variables reverberate through a system (Zivot \& Wang, 2006, pp. $385-416)$.

\section{Results}

As can be seen from Chart 2, the curves present the responses of various components of aggregate demand to an unexpected increase in the effective federal funds rate in the next 40 quarters in the period 1984-2019. Considering the individual IRFs, a time-delayed reaction of variables included in the VAR model to the short-term interest rate shock can be noticed.

In line with economic theory, the reaction function of the economic growth rate shows that the rise in the Fed's interest rate causes a decline in the growth of real GDP, and then there is a long return to equilibrium. Between 1984 and 2007, the maximum impact of the monetary policy tightening on the change in the aggregate demand was observed after about four quarters

${ }^{2}$ IRFs - it makes it possible to identify the strength and speed of the pass-through of monetary policy decisions to economic activity.

${ }^{3}$ FEVD - it measures the contribution of each type of shock to the forecast error variance. 
following the monetary policy shock. This result is in line with the study of Erceg \& Levin (2006, p. 1341-1359). It should also be noted that during the global financial crisis, the interest rate impulse influenced the rate of economic growth with a large delay. The long-lasting negative reaction of this variable was visible between the 7th and 13th quarters after the occurrence of the monetary policy innovation in the period 2008-2019.

It is also worth noting that between 1984 and 2007, the interest rate impulse affected the individual components of the real GDP with varying delays. In particular, on the one hand, real personal consumption expenditures responded the fastest to an increase in the effective federal fund rate. The maximum negative reaction of this variable was visible six quarters after the monetary policy shock. On the other hand, in the case of real fixed investment spending, the response could be seen seven quarters after a positive monetary shock. However, the strength of the interest rate shock's influence on the rate of fixed investment growth was almost eight times greater than on the dynamics of personal consumption expenditures. The positive interest rate impulse had the strongest impact primarily on:

- real durable goods expenditures (after about four quarters);

- real residential investment - the negative reaction of this variable was visible between the 2nd and 9 th quarters.

These results are, in some sense, in line with those of Walsh (2014, pp. 6-7).

In turn, it is worth noting that between 2007 and 2019, the response of all real GDP elements to the monetary policy innovation was delayed, compared to the period 1984-2007. Moreover, the positive interest rate impulse still had the strongest impact on the fixed investment. The in-depth analysis indicates that in the years 2008-2019, the effective federal rate affected residential investment with almost two times less force than in the previous period. These observations may reflect the scale of the disorder which the U.S. economy was subjected to after the collapse of the subprime market in August 2007.

The interaction analysis between the variables included in the VAR model has been supplemented with an assessment of the FEVD. In this study, the share of the interest rate shock in the variance decompositions of the individual variables was adopted as a measure of the relationship between monetary policy and the real sphere of the economy.

The results presented in Table 4 show that between 1984 and 2007, the volatility of the real GDP growth rate at $4 \%$ was explained by the shock of the effective federal funds rate after three years. The relatively largest monetary policy influence on the volatility of major aggregated demand components could be indicated in relation to fixed investment spending. Notice that interest rate shocks accounted for $15 \%$ and $30 \%$ fraction of fixed investments and residential investments, respectively, between the second and fourth years. In turn, the sensitivity of the personal consumption expenditures to monetary policy shocks was marginal and did not exceed $1 \%$ after two years. It is implied that private consumption in the U.S. is less sensitive to interest rates. On the one 
hand, the effect of monetary policy shocks affecting aggregate demand mainly through investment has also been found, among other, by Barran et al. (1996, pp. 1-42) for the EU countries, and Disyatat \& Vongsinsirikul (2003, pp. 389418) for Thailand. On the other hand, this result seems to be in contrast with the findings for the U.S. economy obtaining from the study of Angeloni et al. (2003, pp. 1265-1306).

It is worth emphasizing that during the recent global financial crisis, the structure of the FEVD changed slightly. In particular, it should be noted that the decomposition of the real GDP growth rate and the rate of fixed investment growth did not change compared to the previous period. In the case of the residential investment and the personal consumption expenditures, a significant modification in their variance decomposition took place. Firstly, between 2007 and 2019, in explaining the error of the residential investment forecast, the share of the shock from the interest rate decreased from $30 \%$ to $10 \%$. Secondly, in the period 2007-2019, the variable representing consumption spending (in particular the real durable goods spending) was more sensitive to a shift in the interest rate policy. This result is opposite to the findings of van Zandweghe \& Braxton (2013, p. 24), according to which durable goods expenditures are less sensitive to monetary policy shocks during the economic recovery that occurs after the last crisis.

\section{Conclusion}

The results of this survey showed that between 1984 and 2019, the sensitivity of real consumption spending and real investment expenditures to the interest rate impulse was different, which could be confirmed by several regularities. Firstly, fixed investment spending accounted for a significant part that was responsible for the response of real GDP following the interest rate shock. Secondly, in the case of personal consumption expenditures, durable goods expenses were more sensitive to changes in the Fed's interest rate than spending on services and nondurable goods. In particular, it could be stated that in the period 1984-2007, the positive interest rate impulse was a very strong influence on residential investment. Moreover, the sensitivity of personal consumption spending and all its components to monetary shock was marginal. Therefore, this analysis confirms the hypothesis about the impact of monetary policy on aggregate demand mainly through investments.

In turn, it is worth noting that between 2007 and 2019, the response of all real GDP elements to the monetary policy innovation was delayed, compared to the period 1984-2007. On the one hand, consumption expenditures were characterized by increased sensitivity to interest rate shock. On the other hand, the very low sensitivity of residential investment to the interest rate impulse was noted.

The analysis enables a better understanding of the U.S. monetary policy transmission mechanism, despite all the research limitations, i.e. time hori- 
zon and variables used in the models. The results of this study are significant for monetary authorities and they can be used to provide more efficient decision-making procedures.

Further research can be conducted in three directions. First of all, together with the release of new statistical data, the examined period might be enlarged. Secondly, extended research requires a detailed analysis of the features of the American economy that might have a potential impact on the monetary transmission mechanism. Thirdly, the comparative analysis of the Fed's monetary policy transmission mechanism and other leading central banks in the global financial system can be carried out. In particular, the estimated VAR model can also be used to study the impact of the monetary policy of the European Central Bank and the Bank of England on the economies of the euro area and the United Kingdom, respectively. This possibility is dictated by the fact that for the indicated central banks there are also available statistical data on the shadow rate, estimated by Wu \& Xia (2016).

\section{References}

Akhtar, M.A. (1997). Understanding open market operations. Public Information Department Federal Reserve Bank of New York.

Angeloni, I., Kashyap, A., Benoit, M., \& Terlizzese, D. (2003). The output consumption puzzle: a difference in the monetary transmission mechanism in the Euro area and United States. Journal of Money, Credit, and Banking, 35(6b), 1265-1306. https://doi.org/10.1353/mcb.2004.0018.

Barran, F., Coudert, V., \& Mojon, B. (1996). The transmission of monetary policy in European countries. CEPII Working Paper, 03, 1-41.

Bean, C., Larsen, J., \& Nikolov, K. (2002). Financial frictions and the monetary transmission mechanism: theory, evidence and policy implications. ECB Working Paper, 113, 1-67.

Bernanke, B.S., \& Blinder, A.S. (1992). The federal funds rate and the channels of monetary transmission. The American Economic Review, 82(4), 901-921.

Bernanke, B.S., \& Gertler, M. (1995). Inside the black box: the credit channel of monetary policy transmission. Journal of Economic Perspectives, 9(4), 27-48. https://doi.org/10.1257/jep.9.4.27.

Boivin, J., \& Giannoni, M. P. (2002). Assessing changes in the monetary transmission mechanism: a VAR approach. Federal Reserve Bank of New York Economic Policy Review, 8(1), 97-111.

Brózda, D. (2016). Transmission mechanism of the Federal Reserve System's monetary policy in the conditions of zero bound on nominal interest rates. Equilibrium. Quarterly Journal of Economics and Economic Policy, 11(4), 751767. https://doi.org/10.12775/EQUIL.2016.034.

Brózda-Wilamek, D. (2020). The effectiveness of the Federal Reserve System's monetary policy in the years 1962-2018. Studia Prawno-Ekonomiczne, 117, 163-182. https://doi.org/10.26485/SPE/2020/117/10. 
Brunner, A.D. (1994). The federal funds rate and the implementation of monetary policy: estimating the federal reserve's reaction function. International Finance Discussion Papers, 1994(466), 1-46. https://doi.org/10.17016/ ifdp.1994.466.

Christiano, L., Eichenbaum, M., \& Evans, C. (1999). Monetary policy shocks: what have we learned, and to what end. In J.B. Taylor, \& M. Woodford (Eds.), Handbook of Macroeconomics, 1(Part A), 65-148. Elsevier. https:// doi.org/10.1016/S1574-0048(99)01005-8.

Christiano, L., Eichenbaum, M., \& Evans, C. (2005). Nominal rigidities and the dynamic effects of shocks to monetary policy. Journal of Political Economy, 113(1), 1-45. https://doi.org/10.1086/426038.

Christiano, L., Eichenbaum, M., \& Trabandt, M. (2015). Understanding the great recession. American Economic Journal: Macroeconomics, 7(1), 110167. https://doi.org/10.1257/mac.20140104.

Chung, H., Laforte, J. P., Reifschneider, D., \& Williams, J. C. (2011). Estimating the macroeconomic effects of the Fed's asset purchases. Federal Reserve Bank of San Francisco Economic Letter, 2011(3), 1-5.

Cochrane, J. H. (1998). What do the VARs mean: measuring the output effects of monetary policy. Journal of Monetary Economics, 4l(2), 277-300. https:// doi.org/10.1016/S0304-3932(97)00075-5.

Disyatat, P., \& Vongsinsirikul, P. (2003). Monetary policy and the transmission mechanism in Thailand. Journal of Asian Economics, 14(3), 389-418. https:// doi.org/10.1016/S1049-0078(03)00034-4.

Endut, N., Morley, J., \& Tien, P. (2018). The changing transmission mechanism of US monetary policy. Empirical Economics, 54(3), 959-987. https:// doi.org/10.1007/s00181-017-1240-7.

Erceg, C., \& Levin, A. (2006). Optimal monetary policy with durable consumption goods. Journal of Monetary Economics, 53(7), 1341-1359. https:// doi.org/10.1016/j.jmoneco.2005.05.005.

Federal Reserve Bank of Atlanta. (2019). Wu-Xia shadow federal funds rate. Retrieved 21.06.2020 from https://www.atlantafed.org/cqer/research/wuxia-shadow-federal-funds-rate.aspx.

Höppner, F., Melzer, C., \& Neumann, T. (2008). Changing effects of monetary policy in the US: evidence from a time-varying coefficient VAR. Applied Economics, 40(18), 2353-2360.https://doi.org/10.1080/00036840600970112.

Khemraj, T., \& Yu, S. (2016). The effectiveness of quantitative easing: new evidence on private investment. Applied Economics, 48(28), 2625-2635. https://doi.org/10.1080/00036846.2015.1125439.

Khundrakpam, J. K. (2012). Estimating impacts of monetary policy on aggregate demand in India. RBI Working Paper Series, 2012(18), 1-21.

Kwiatkowski, D., Philips, P.C.B., Schmidt, P., \& Shin, Y. (1992). Testing the null hypothesis ofstationaryagainst thealternative ofaunitroot. JournalofEconometrics, 54(1-3), 159-178. https://doi.org/10.1016/0304-4076(92)90104-y. 
Litterman, R.B., \& Weiss, L. (1985). Money, real interest rates and output: a reinterpretation of postwar US data. Econometrica, 53(1), 129-156. https:// doi.org/10.2307/1911728.

Mishkin, F.S. (1996). The channel of monetary transmission: lessons for monetary policy. NBER Working Paper Series, 5464, 1-29. https://doi. org/10.3386/w5464.

Monacelli, T. (2009). New Keynesian models, durable goods, and collateral constraints. Journal of Monetary Economics, 56(2), 242-254. https://doi. org/10.1016/j.jmoneco.2008.09.013.

Rudebusch, G.D. (1998). Do measures of monetary policy in a VAR make sense. International Economic Review, 39(4), 907-931. https://doi. org/10.2307/2527344.

Sims, C.A. (1980). Macroeconomics and reality. Econometrica, 48(1), 1-48. https://doi.org/10.2307/1912017.

Sims, E.R., \& Wu, J.C. (2020). Federal Reserve policy in a world of low interest rates. Cato Journal, 40(2), 343-360. https://doi.org/10.36009/CJ.40.2.5.

Stock, J.H., \& Watson, M.W. (2001). Vector autoregression. Journal of Economic Perspectives, 15(4), 101-115. https://doi.org/10.1257/jep.15.4.101.

van Zandweghe, W. (2015). Monetary policy shocks and aggregate supply. Federal Reserve Bank of Kansas City Economic Review, Q III, 1-56.

van Zandweghe, W., \& Braxton, J.C. (2013). Has durable goods spending become less sensitive to interest rates. Federal Reserve Bank of Kansas City Economic Review, Q IV, 5-27.

Walsh, C.E. (2014). Monetary policy transmission channels and policy instruments. Retrieved 09.10.2021 from https://people.ucsc.edu/ walshc/MyPapers/ ChannelsandInstruments.pdf.

Wu, J.C., Xia, F.D. (2016). Measuring the macroeconomic impact of monetary policy at the zero lower bound. Journal of Money, Credit and Banking, 48(2-3), 253-291. https://doi.org/10.1111/jmcb.12300.

Zivot, E., \& Wang, J. (2006). Modeling financial time series with S-PLUS. Springer. https://doi.org/10.1007/978-0-387-32348-0.

\section{Acknowledgements}

Author contributions: author has given an approval to the final version of the article.

Funding: this research was undertaken as part of the The impact of the major central banks monetary policy on the economy project and was fully funded by the University of Lodz, Faculty of Economics and Sociology (B2011200002168.02). 


\section{Appendix}

Table 1.

ADF test results for time series in the I and II VAR model (boundary significance levels)

\begin{tabular}{|c|c|c|c|c|c|c|}
\hline \multirow{2}{*}{ Variable } & \multicolumn{3}{|c|}{$1984: 1-2007: 3(\mathrm{~T}=95)$} & \multicolumn{3}{|c|}{$2007: 4-2019: 4(T=49)$} \\
\hline & 1 & 2 & 3 & 1 & 2 & 3 \\
\hline$\Delta \mathrm{GDP}_{\mathrm{t}}$ & $0.032^{* *}$ & $0.000^{* * *}$ & $0.001^{* * *}$ & $0.001^{* * *}$ & $0.001^{* * *}$ & $0.001^{* * *}$ \\
\hline$\triangle \mathrm{PCE}_{\mathrm{t}}$ & $0.061^{*}$ & $0.003^{* * *}$ & $0.021^{* *}$ & 0.216 & 0.217 & $0.018^{* *}$ \\
\hline$\Delta \mathrm{DG}_{\mathrm{t}}$ & $0.016^{* *}$ & $0.000^{* * *}$ & $0.000^{* * *}$ & $0.011^{* *}$ & $0.000^{* * *}$ & $0.000^{* * *}$ \\
\hline$\Delta \mathrm{ND}_{\mathrm{t}}$ & $0.069^{*}$ & $0.000^{* * *}$ & $0.000^{* * *}$ & 0.373 & 0.542 & $0.000^{* * *}$ \\
\hline$\Delta \mathrm{S}_{\mathrm{t}}$ & 0.292 & 0.116 & 0.129 & 0.289 & $0.005^{* * *}$ & $0.003^{* * *}$ \\
\hline$\Delta \mathrm{FI}_{\mathrm{t}}$ & $0.000^{* * *}$ & $0.001^{* * *}$ & $0.007^{* * *}$ & $0.007^{* * *}$ & $0.059^{*}$ & 0.170 \\
\hline$\Delta \mathrm{NR}_{\mathrm{t}}$ & $0.006^{* * *}$ & $0.001^{* * *}$ & $0.009^{* * *}$ & $0.002^{* * *}$ & $0.017^{* *}$ & $0.066^{*}$ \\
\hline$\Delta \mathrm{R}_{\mathrm{t}}$ & $0.000^{* * *}$ & $0.008^{* * *}$ & $0.035^{* *}$ & $0.035^{* *}$ & 0.264 & 0.623 \\
\hline $\mathrm{i}_{\mathrm{t}}$ & 0.153 & 0.152 & $0.002^{* * *}$ & $0.001^{* * *}$ & $0.018^{* * *}$ & $0.028^{* *}$ \\
\hline$\Delta \mathrm{p}_{\mathrm{t}}$ & 0.348 & $0.050^{* *}$ & $0.094^{*}$ & $0.000^{* * *}$ & $0.000^{* * *}$ & $0.000^{* * *}$ \\
\hline $\mathrm{z}_{\mathrm{t}}$ & $0.035^{* *}$ & 0.175 & $0.002^{* * *}$ & $0.048^{* *}$ & $0.075^{*}$ & 0.299 \\
\hline
\end{tabular}

Notes:

${ }^{*} \mathrm{p}<0.10 ;{ }^{* *} \mathrm{p}<0.05 ;{ }^{* * *} \mathrm{p}<0.01$.

Null hypothesis: the unit root occurs.

1 - test without a constant, 2 - test with a constant, 3 - test with a constant and linear trend.

Source: Own preparation.

Table 2.

KPSS test results for time series in the I and II VAR model (test statistics)

\begin{tabular}{|c|c|c|c|c|c|c|c|c|c|c|c|c|}
\hline \multirow{4}{*}{$\begin{array}{l}\text { Critical } \\
\text { values }\end{array}$} & \multicolumn{6}{|c|}{$1984: 1-2007: 3(\mathrm{~T}=95)$} & \multicolumn{6}{|c|}{$2007: 4-2019: 4(T=49)$} \\
\hline & \multicolumn{3}{|c|}{1} & \multicolumn{3}{|c|}{2} & \multicolumn{3}{|c|}{1} & \multicolumn{3}{|c|}{2} \\
\hline & $10 \%$ & $5 \%$ & $1 \%$ & $10 \%$ & $5 \%$ & $1 \%$ & $10 \%$ & $5 \%$ & $1 \%$ & $10 \%$ & $5 \%$ & $1 \%$ \\
\hline & 0.350 & 0.462 & 0.734 & 0.120 & 0.148 & 0.215 & 0.351 & 0.462 & 0.724 & 0.121 & 0.149 & 0.213 \\
\hline$\Delta \mathrm{GDP}_{\mathrm{t}}$ & & 0.160 & & & 0.093 & & & 0.430 & & & 0.101 & \\
\hline$\triangle \mathrm{PCE}_{\mathrm{t}}$ & & 0.127 & & & 0.129 & & & 0.711 & & & 0.135 & \\
\hline$\Delta \mathrm{DG}_{\mathrm{t}}$ & & 0.176 & & & 0.132 & & & 0.467 & & & 0.164 & \\
\hline$\Delta \mathrm{ND}_{\mathrm{t}}$ & & 0.169 & & & 0.094 & & & 0.802 & & & 0.125 & \\
\hline$\Delta \mathrm{S}_{\mathrm{t}}$ & & 0.363 & & & 0.067 & & & 0.576 & & & 0.071 & \\
\hline$\Delta \mathrm{FI}_{\mathrm{t}}$ & & 0.141 & & & 0.143 & & & 0.285 & & & 0.179 & \\
\hline$\Delta \mathrm{NR}_{\mathrm{t}}$ & & 0.131 & & & 0.107 & & & 0.158 & & & 0.115 & \\
\hline$\Delta \mathrm{R}_{\mathrm{t}}$ & & 0.136 & & & 0.123 & & & 0.466 & & & 0.257 & \\
\hline$i_{t}$ & & 1.367 & & & 0.108 & & & 0.342 & & & 0.308 & \\
\hline$\Delta \mathrm{p}_{\mathrm{t}}$ & & 0.590 & & & 0.124 & & & 0.068 & & & 0.063 & \\
\hline$z_{t}$ & & 2.080 & & & 0.157 & & & 0.677 & & & 0.199 & \\
\hline
\end{tabular}

Notes:

Null hypothesis: stationary process.

1 - test KPSS with a constant; 2 - test KPSS with a constant and linear trend.

Source: Own preparation. 
Table 3.

The values of the information criteria for models I and II which included total real GDP variable

\begin{tabular}{lccccc}
\hline lags & logLik & $\mathrm{p}(\mathrm{LR})$ & $\mathrm{AIC}$ & $\mathrm{BIC}$ & HQC \\
\hline & & & $1984: 1-2007: 3$ & \\
1 & -452.46721 & 9.946678 & $10.484336^{*}$ & 10.163932 \\
2 & -417.56162 & 0.00000 & $9.548666^{*}$ & 10.516451 & $9.939723^{*}$ \\
3 & -403.47436 & 0.03013 & 9.588934 & 10.986845 & 10.153795 \\
4 & -394.45074 & 0.32114 & 9.735805 & 11.563843 & 10.474470 \\
\hline & & & $2007: 4-2019: 4$ & \\
1 & -204.31378 & 9.346407 & $10.126075^{*}$ & 9.641045 \\
2 & -177.82390 & 0.00001 & 8.909329 & 10.312730 & $9.439676^{*}$ \\
3 & -161.33931 & 0.00746 & 8.889138 & 10.916273 & 9.655195 \\
4 & -137.63924 & 0.00006 & $8.568302^{*}$ & 11.219170 & 9.570068 \\
\hline
\end{tabular}

Notes:

The asterisks $\left({ }^{*}\right)$ indicate the best (that is, minimized) values of the respective information criteria.

Source: Own preparation.

Table 4.

The share of the interest rate shock in the FEVD of aggregate demand components included in the VAR I and II models (in \%)

\begin{tabular}{|c|c|c|c|c|c|c|c|c|}
\hline \multirow{2}{*}{$\begin{array}{l}\text { On average } \\
\text { per year }\end{array}$} & \multicolumn{2}{|c|}{$\triangle \mathrm{GDP}_{\mathrm{t}}$} & \multicolumn{2}{|c|}{$\triangle \mathrm{PCE}_{t}$} & \multicolumn{2}{|c|}{$\Delta \mathrm{FI}_{\mathrm{t}}$} & \multicolumn{2}{|c|}{$\Delta \mathrm{R}_{\mathrm{t}}$} \\
\hline & $\begin{array}{l}1984: 1- \\
2007: 3 \\
\end{array}$ & $\begin{array}{c}2007: 4- \\
2019: 4\end{array}$ & $\begin{array}{l}1984: 1- \\
2007: 3 \\
\end{array}$ & $\begin{array}{c}2007: 4- \\
2019: 4 \\
\end{array}$ & $\begin{array}{l}1984: 1- \\
2007: 3 \\
\end{array}$ & $\begin{array}{c}2007: 4- \\
2019: 4 \\
\end{array}$ & $\begin{array}{l}1984: 1- \\
2007: 3 \\
\end{array}$ & $\begin{array}{c}2007: 4- \\
2019: 4 \\
\end{array}$ \\
\hline 1 & 1 & 1 & 0 & 0 & 1 & 1 & 8 & 2 \\
\hline 2 & 3 & 1 & 1 & 1 & 7 & 3 & 21 & 4 \\
\hline 3 & 4 & 2 & 1 & 3 & 12 & 7 & 28 & 7 \\
\hline 4 & 4 & 3 & 1 & 5 & 15 & 10 & 30 & 9 \\
\hline 5 & 4 & 3 & 1 & 6 & 15 & 12 & 30 & 10 \\
\hline 6 & 4 & 4 & 1 & 6 & 15 & 13 & 30 & 11 \\
\hline \multirow[b]{2}{*}{$\begin{array}{l}\text { On average } \\
\text { per year }\end{array}$} & \multicolumn{2}{|c|}{$\Delta \mathrm{DG}_{\mathrm{t}}$} & \multicolumn{2}{|c|}{$\Delta \mathrm{ND}_{\mathrm{t}}$} & \multicolumn{2}{|c|}{$\Delta S_{t}$} & \multicolumn{2}{|c|}{$\Delta \mathrm{NR}_{\mathrm{t}}$} \\
\hline & $\begin{array}{l}1984: 1- \\
2007: 3\end{array}$ & $\begin{array}{c}2007: 4- \\
2019: 4\end{array}$ & $\begin{array}{l}1984: 1- \\
2007: 3\end{array}$ & $\begin{array}{c}2007: 4- \\
2019: 4\end{array}$ & $\begin{array}{l}1984: 1- \\
2007: 3\end{array}$ & $\begin{array}{c}2007: 4- \\
2019: 4\end{array}$ & $\begin{array}{l}1984: 1- \\
2007: 3\end{array}$ & $\begin{array}{c}2007: 4- \\
2019: 4\end{array}$ \\
\hline 1 & 0 & 1 & 0 & 0 & 0 & 0 & 2 & 0 \\
\hline 2 & 1 & 2 & 1 & 1 & 0 & 1 & 3 & 1 \\
\hline 3 & 1 & 4 & 2 & 1 & 0 & 1 & 5 & 4 \\
\hline 4 & 1 & 6 & 2 & 2 & 1 & 1 & 6 & 7 \\
\hline 5 & 1 & 7 & 2 & 3 & 1 & 2 & 6 & 9 \\
\hline 6 & 1 & 7 & 2 & 3 & 1 & 2 & 6 & 9 \\
\hline
\end{tabular}

Source: Own preparation. 


\section{Chart 1.}

The level of the shadow federal funds rate in the period 2004-2019 (in \%)

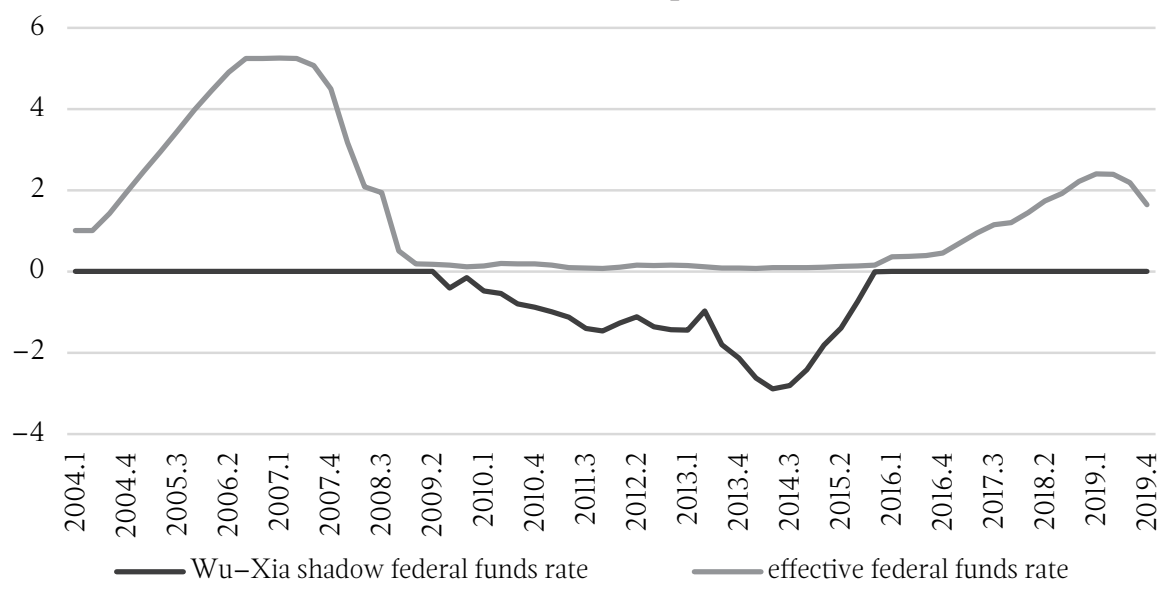

Source: Own preparation based on Federal Reserve Bank of Atlanta (2019). 


\section{Chart 2.}

The IRFs of variables representing various components of aggregate demand to an interest rate shock in the period 1984-2019
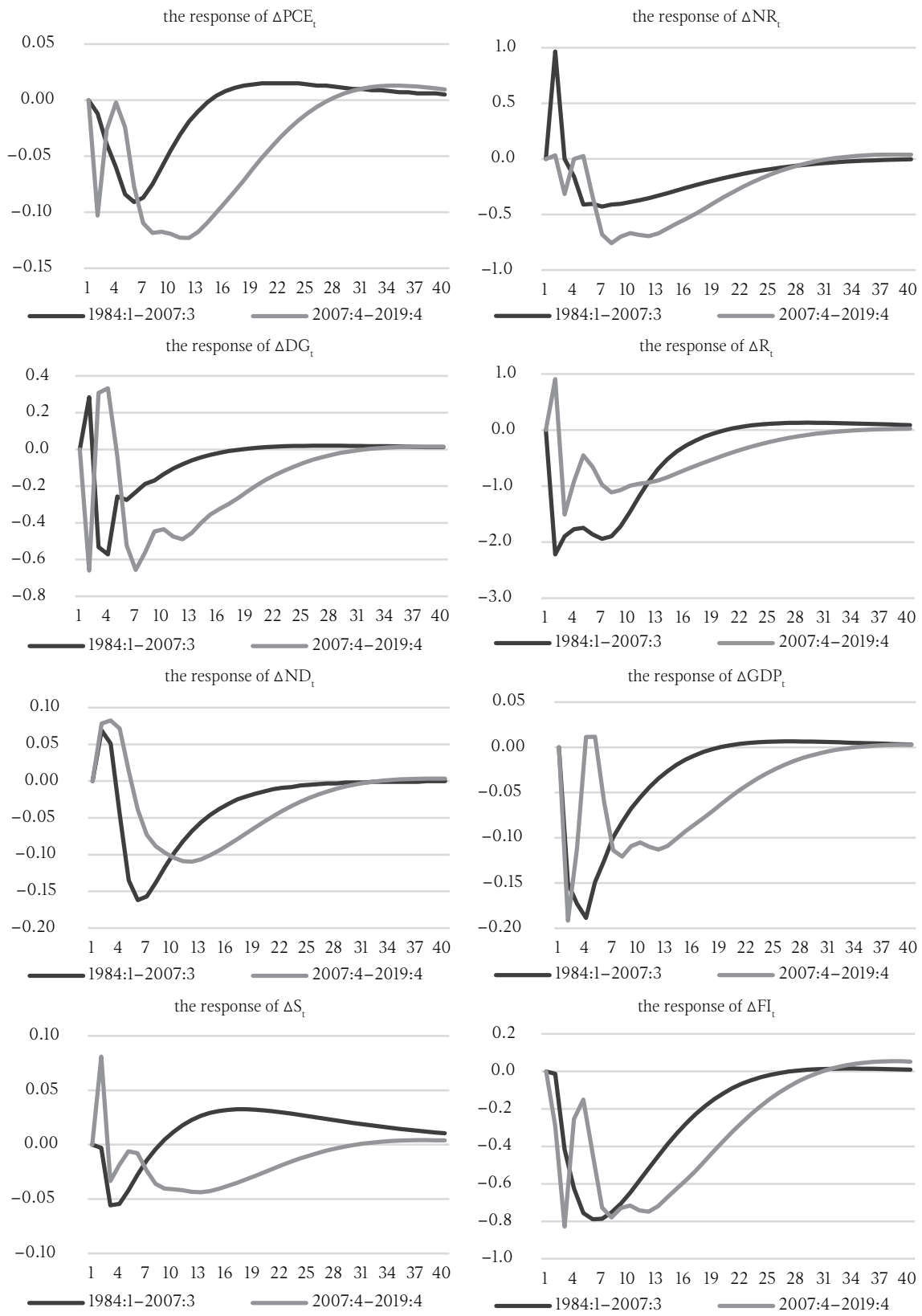

Source: Own preparation. 